\title{
Incidental Finding of Phlebolith in a Patient with Chronic Inflammatory Gingival Enlargement - A Case Report
}

\author{
Roshni Ramesh ${ }^{1 *}$, Arun Sadasivan ${ }^{2}$ and Pradheesh Sathyan ${ }^{3}$ \\ ${ }^{1}$ Department of Periodontics, Government Dental College, India \\ ${ }^{2}$ Department of Periodontics, Sree Mookambika Institute of Dental Sciences, India \\ ${ }^{3}$ Department of Oral Pathology, Government Dental College, India
}

Submission: April 13, 2018; Published: May 23, 2018

*Corresponding author: Roshni Ramesh, Professor, Department of Periodontics, Government Dental College, Trivandrum-695011, Kerala, India, Tel: 919847230052; Email: roshni_arun@hotmail.com

\begin{abstract}
The aim of this case report is to alert clinicians to the possibility of occurrence of vascular thrombi in the mouth. Phleboliths (calcified thrombi) are a common finding, especially in the pelvic veins. They are usually associated with vascular malformations and are generally multiple. Here in we report an incidental finding of a phlebolith associated with chronic inflammatory gingival enlargement and not associated with any other vascular lesion. Although phleboliths not associated with other vascular lesions are not a common finding in the oral cavity, clinicians should be aware of the existence of such lesions. Phleboliths associated with gingival enlargements even though rare do occur. Dentists need to be aware of the existence of such lesions and should rule out the possibility of vascular lesions in such cases.
\end{abstract}

Keywords: Calcified body; Gingival enlargement; Intravascular thrombus; Phlebolith

\section{Introduction}

Phleboloths are calcified thrombi that occur in vascular channels associated with hemangiomas and other vascular lesions as venolymphatic malformations and are caused by blood stasis [1] or even trauma [2]. They are usually multiple and may vary in number from several to dozens within the affected area. They are most commonly seen in the pelvic area within prostatic, uterine or intestinal veins. Phleboliths are not unusual in the head and neck region, but only a few cases of phleboliths not associated with other vascular anomalies have been reported in the literature [35].

Phleboliths are commonly found on routine radiographs of cases diagnosed as vascular malformations although they are better detected by computerized tomography $[6,7]$.

Besides imaging techniques, biopsy followed by microscopic examination can help in the final diagnosis.

Even though phleboliths are not rare in the head and neck, buccal soft tissues rarely contain lesions that include calcifications. Here in we report an incidental finding of calcification within a chronic inflammatory gingival enlargement. To the best of our knowledge, this could be the first reported instance of occurrence of phlebolith in a case of gingival enlargement. By presenting this case, we aim to alert clinicians regarding the importance of biopsy in all cases of gingival enlargements to rule out the possibility of vascular malformations.

\section{Case Description}

A 32 - year old woman was referred to our clinic presenting with generalised gingival enlargement. She reported difficulty in mastication and speech. Patient's medical history was noncontributory.

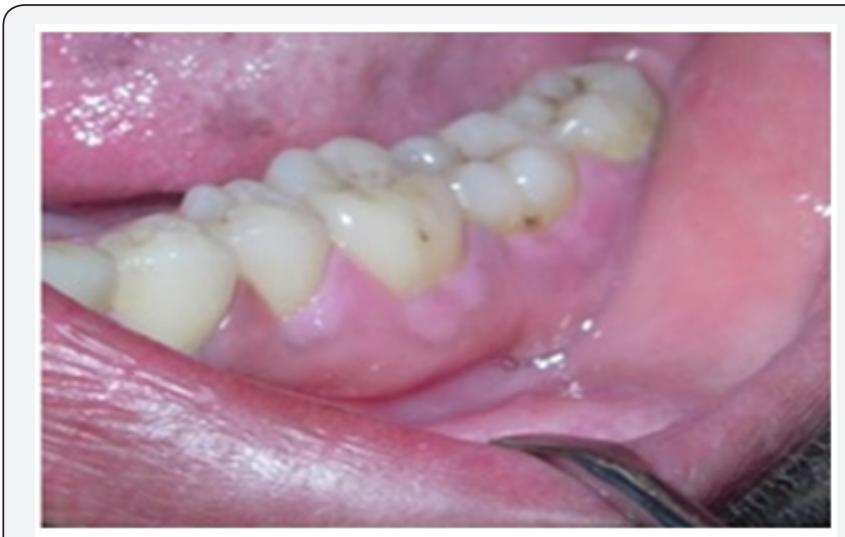

Figure 1a: Chronic inflammatory gingival enlargement in the mandibular left posterior region. 


\section{Advances in Dentistry \& Oral Health}

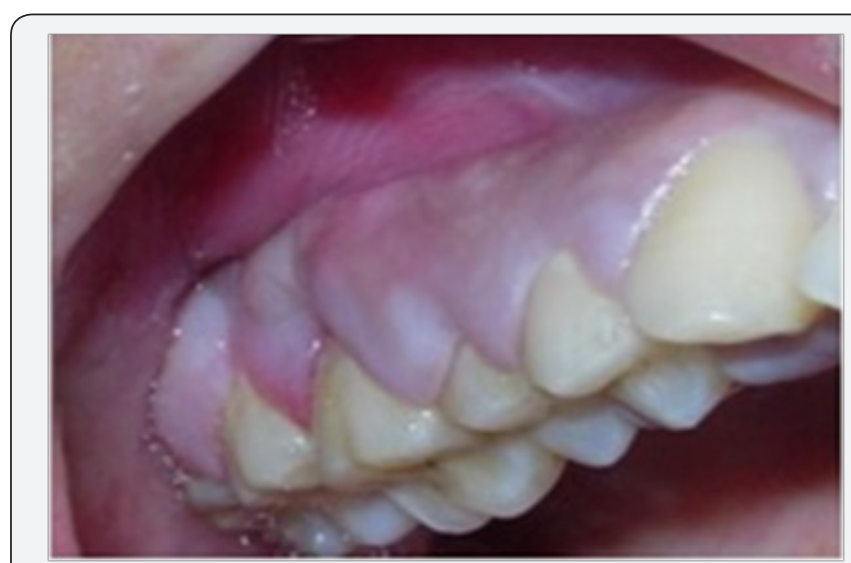

Figure 1b: Chronic inflammatory gingival enlargement in the maxillary right posterior region.

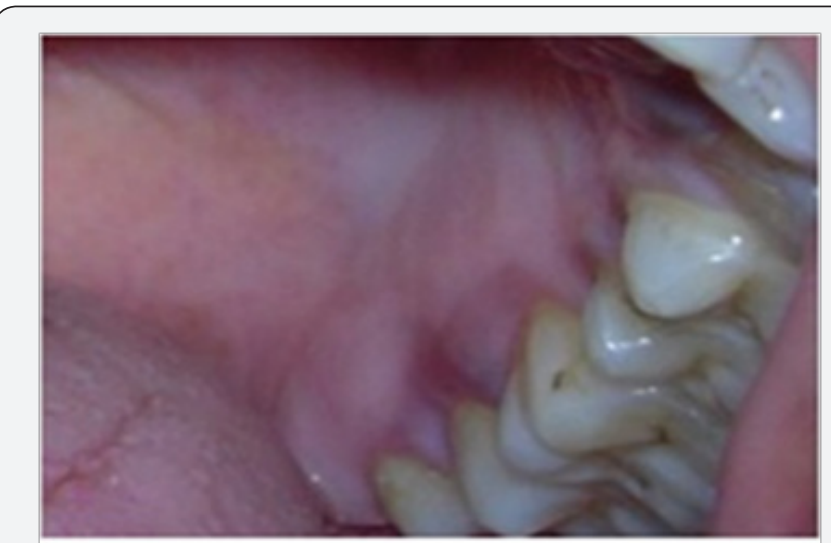

Figure 1c: Chronic inflammatory gingival enlargement in the maxillary left posterior region (palatal aspect).

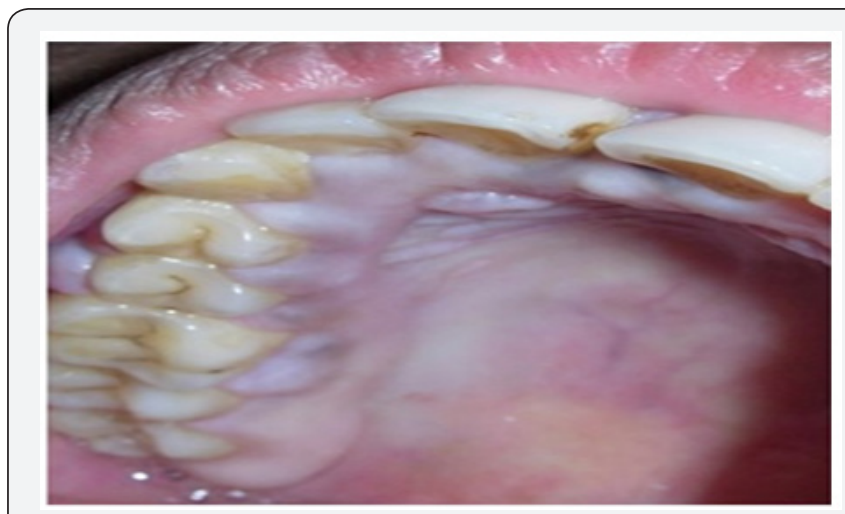

Figure 1d: Chronic inflammatory gingival enlargement in the maxillary right posterior region (palatal aspect).

On intraoral examination, generalised, diffuse, fibroedematous overgrowth of gingival tissues of both the maxillary and mandibular teeth was seen. The severity of enlargement was more in relation to posterior teeth (Figure 1a-1d). The probing depth in the posterior region ranged from 4 to $6 \mathrm{~mm}$. Plaque accumulation was moderate and the gingiva was inflamed with a pale red colour. The condition was not painful, but there was mild bleeding on probing. The teeth were not mobile.
Intraoral periapical and panoramic radiographs were taken. Radiographs revealed generalised mild bone loss with slight interproximal bone loss (Figure 2). Radiographs did not reveal any bony lesion. General examination and blood investigations were done to rule out any medical involvement. Serum calcium level and routine biochemical tests were normal. Results of complete blood count indicated no significant abnormalities. Based on the above findings, a provisional diagnosis of chronic inflammatory gingival enlargement was made.

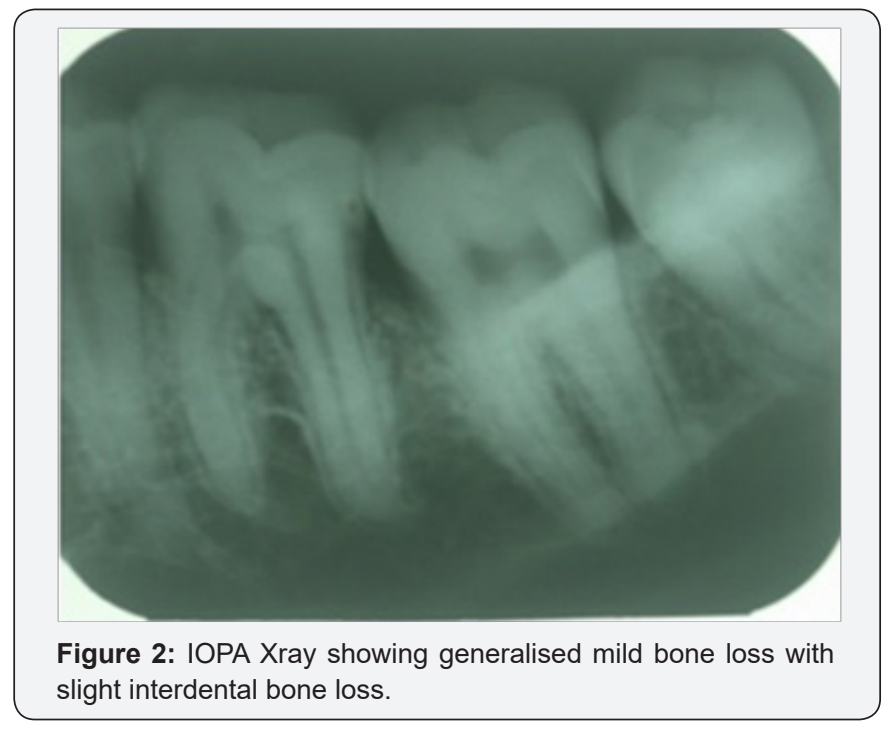

After completion of oral prophylaxis, internal bevel gingivectomy with open flap debridement was done first in the mandibular left posterior quadrant. The excised gingival tissue was sent for histopathological examination.

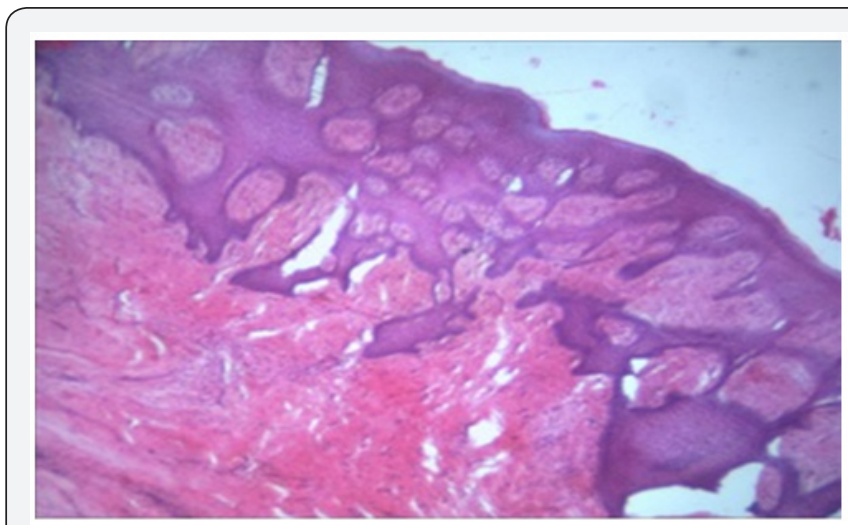

Figure 3: 40x magnification. Hyperplastic epithelium growing in an arcading pattern, with collagenous connective tissue.

Microscopic examination revealed parakeratinized, hyperplastic stratified squamous epithelium in association with a fibrovascular connective tissue stroma (Figure 3). Acanthosis was noted in some foci while in other areas the epithelium showed long rete pegs. The connective tissue was mild to moderately collagenous. The connective tissue showed diffuse, mixed inflammatory cell infiltrate with numerous engorged blood vessels, endothelial proliferation and extravasated red blood cells. The histopathological examination of the excised tissues from 
the mandibular left posterior region showed calcified structures within the vascular spaces in addition to the above findings. The presence of the calcified structure seen intravascularly as well as its structure seems to indicate a phlebolith rather than any other type of calcification (Figure 4 \& 5).

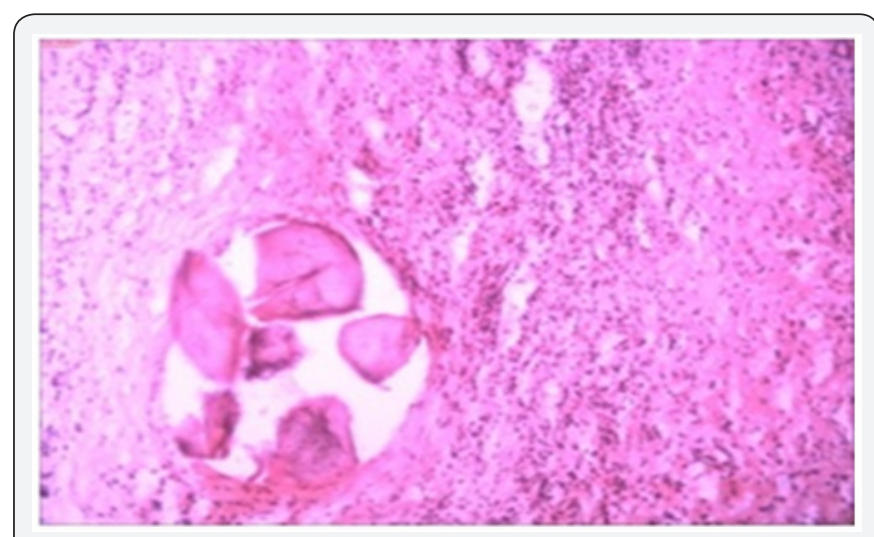

Figure 4: 100x magnification. Phlebolith with lamellar pattern of calcification in a collagenous, moderately inflamed connective tissue stroma.

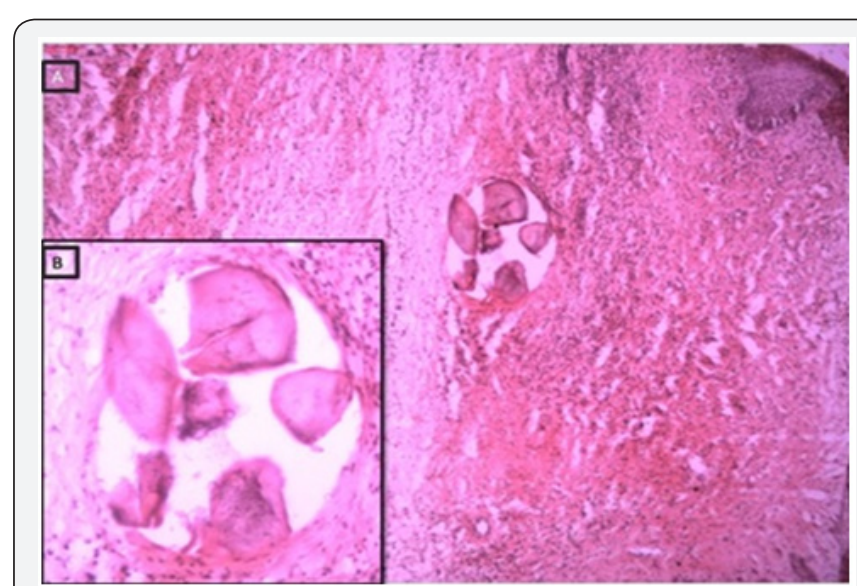

Figure 5: 40x magnification. Phlebolith with lamellar pattern of calcification in a collagenous, moderately inflamed connective tissue stroma.

Internal bevel gingivectomy with open flap debridement was completed in all the other quadrants. Histopathological examination of the excised tissues in the rest of the quadrants did not show any calcification. The patient was followed without any complication after surgery. At the end of one year no evidence of recurrence was observed.

\section{Discussion}

Phleboliths are calcified thrombi commonly seen as multiple calcifications associated with vascular malformations or hemangiomas [1,2 ,6,7,8-19]. Phleboliths not associated with other vascular lesions are uncommon [3-5]. We have reported here in a case of chronic inflammatory gingival enlargement but with an unusual finding of an intravascular phlebolith. As the familial, medical and drug histories were not contributory, a diagnosis of chronic inflammatory gingival enlargement was made. The histopathological evaluation results of the biopsied tissues in this case were similar to that of any inflammatory hyperplasia. The presence of calculi with characteristic concentric lamination was suggestive of phlebolith. No vascular anomalies were seen in the present case.

The pathogenesis of phleboliths usually involves an organized thrombus produced when the peripheral blood flow slows. The thrombus calcifies, forming the core of the phlebolith. The fibrinous component undergoes secondary calcification and becomes attached. Repetition of this process causes enlargement of the phlebolith [8]. In the present case, the enlargement had an inflammatory component that was responsible for increase in vascularity and blood flow to the area. The chronicity of the condition may have led to a decrease in this inflammatory component as the lesion got fibrosed. As a result, the newly formed vascular channels may have had a relative stagnation in blood flow giving rise to conditions favouring the formation of phlebolith. This finding is unique in a case of gingival enlargement and hence cannot be explained further until more cases are encountered or reported.

Medline and Web of Science databases were searched for articles reported in the English literature from 1970 to 2015 describing cases of phleboliths in the oral region. There were only five articles reported with multiple and four with solitary phleboliths not associated with other vascular lesions. The reviewed literature showed that phleboliths of the oral cavity can be found in infants to elderly individuals, but it mainly occurs between the first and third decades of life. The search of literature for the presence of phlebolith within a gingival enlargement did not yield any result.

Phleboliths are diagnosed by physical and imaging examinations and confirmed by microscopy (HE stain). However in our case the presence of phlebolith within the gingival enlargement was an incidental finding when the excised tissue was examined histopathologically. To the best of our knowledge, this could be the first reported instance of occurrence of phlebolith in a case of gingival enlargement.

\section{Conclusion}

All gingival enlargements should be subjected to histopathological examinations. Findings such as phleboliths are usually associated with vascular malformations. Although phleboliths not associated with other vascular lesions are not a common finding in the oral cavity, clinicians should be aware of the existence of such lesions.

\section{Clinical Significance}

When you evaluate an oral soft tissue mass with a calculus like body, it will usually be a phlebolith associated with a vascular lesion. Cases of phleboliths not associated with other vascular lesions are rarely reported in the literature. Despite the rarity of the condition, dentists need to be aware of the existence of such conditions in the oral cavity. 


\section{References}

1. HA Altug, V Buyuksoy, KM Okcu, N Dogan (2007) Hemangiomas of the head and neck with phleboliths: clinical features, diagnostic imaging and treatment of 3 cases. Oral Surg Oral Med Oral Pathol Oral Radiol Endod 103(3): E60-E64.

2. L Mandel, MA Perrino (2010) Phleboliths and the vascular maxillofacial lesion. Journal of Oral and Maxillofacial Surgery 68(8): 1973-1976.

3. N Zachariades, G Rallis, J Papademetriou, E Konsolaki, S Markaki, et al. (1991) Phleboliths. A report of three unusual cases. British Journal of Oral and Maxillofacial Surgery 29(2): 117-119.

4. H Kurita, M Chino, K Kurashina, A Kotani (1994) Phlebothrombosis with phlebolith of the tongue. Oral Surgery Oral Medicine Oral Pathology 77(6): 552.

5. H Kato, Y Ota, M Sasaki, T Arai, Y Sekido, et al. (2012) A phlebolith in the anterior portion of the masseter muscle. Tokai Journal of Experimental and Clinical Medicine 37(1): 25-29.

6. CC Chuang, HC Lin, CW Huang (2005) Submandibular cavernous hemangiomas with multiple phleboliths masquerading as sialolithiasis. Journal of the Chinese Medical Association 68(9): 441-443.

7. K Orhan, M Icen, S Aksoy, H Avsever, G Akcicek (2012) Large arteriovenous malformation of the maxillofacial region with multiple phleboliths. Oral Surgery Oral Medicine Oral Pathology Oral Radiology 114(4): e147-e158.

8. BO Riordan (1974) Phleboliths and salivary calculi. British Journal of Oral Surgery 12(2): 119-131.

9. CJ Keathley, RL Campbell, JW Isbell (1983) Arteriovenous malformation and associated phleboliths. Report of a case Oral Surgery Oral Medicine Oral Pathology 56(2): 132-135.

10. P Scolozzi, F Laurent, T Lombardi, M Ritcher (2003) Intraoral venous malformation presenting with multiple phleboliths. Oral Surgery Oral Medicine Oral Pathology Oral Radiology 96(2): 197-200.
11. M Gunge, H Yamamoto, $\mathrm{T}$ Sakae, $\mathrm{T}$ Katoh, $\mathrm{H}$ Izumi (1987) Venous hemangioma with phleboliths - a case study using immunohistochemistry, scanning electron microscopy and $\mathrm{x}$ ray microdiffraction. The Journal of Nihon University School of Dentistry 29(3): 211-220.

12. TM Gharaibeh, RA Safadi, MA Rawashdeh, HM Hammad (2010) Plunging arteriovenous malformation in the floor of the mouth: a case report. British Journal of Oral and Maxillofacial Surgery 48(8): e35-e37.

13. N Ikegami, K Nishijima (1984) Hemangioma of the buccal pad with phlebolithiasis: report of a case. Acta Medica Okayama 38(1): 79-87.

14. K Sano, A Ogawa, T Inokuchi, H Takahashi, K Hisatsune (1988) Buccal hemangioma with phleboliths. Report of two cases Oral Surgery Oral Medicine Oral Pathology 65(2): 151-156.

15. JR Hupp (1989) Facial phleboliths. Oral Surgery Oral Medicine Oral Pathology 67(3): 361.

16. H Cankaya, O Unal, S Ugras, K Yuca, M Kiris (2003) Hemangioma with phleboliths in the sublingual gland : as a cause of submental opacity. Tohoku Journal of Experimental Medicine 199(3): 187-191.

17. YX Su, GQ Liao, L Wang, YJ Liang, M Chu, et al. (2009) Sialoliths or phleboliths? Laryngoscope 119(7): 1344-1347.

18. HJ Choi, JC Lee, JH Kim, YM Lee, HJ Lee (2013) Cavernous hemangioma with large phlebolith of the parotid gland", The Journal of Craniofacial Surgery 24(6): e621-e623.

19. H Kanaya, Y Saito, N Gama, W Konno, H Hirabayashi, et al. (2008) Intramuscular hemangioma of masseter muscle with prominent formation of phleboliths: a case report. Auris Nasus Larynx 35(4): 587 591.

\section{Your next submission with Juniper Publishers will reach you the below assets}

- Quality Editorial service

- Swift Peer Review

- Reprints availability

- E-prints Service

- Manuscript Podcast for convenient understanding

- Global attainment for your research

- Manuscript accessibility in different formats

( Pdf, E-pub, Full Text, Audio)

- Unceasing customer service

Track the below URL for one-step submission https://juniperpublishers.com/online-submission.php 